\title{
Sequestration of carbon dioxide - influence of coal surface chemistry
}

\author{
Agnieszka Orzechowska-Zięba ${ }^{1, a}$, Katarzyna Zarębska ${ }^{1}$, Paweł Baran ${ }^{1}$ and Agnieszka Ćwik1 \\ ${ }^{1}$ AGH University of Science and Technology, Faculty of Energy and Fuels, Aleja Mickiewicza 30, 30-059 Cracow, Poland
}

\begin{abstract}
The physical gas adsorption is a widely used method for the characterisation of the solids porosity. The water steam, primarilydue to its physicochemical properties and ease of use in the experiment has great potential as a sorbate. When applied to coal, water steam allows to determine the quantity of primary adsorption centers as measurement of interaction of molecules adsorbed to the surface of the adsorbent. In order to determine the adsorption capacity and the chemical nature of the coal surface, adsorption / desorption of water vapour to the selected coals was examined at $303 \mathrm{~K}$, using a volumetric method. The presence of water in the coal may affect on the sorption properties of other molecules. The analysis of the results show that the coals of low rank and a high content of oxygen functional groups, which are the active sites, showed a greater affinity to absorbing water molecules. Adsorption isotherms were compiled through approximating the Langmuir and BET linear equation to measurement data. Based on the adsorption equation, the amount of adsorption centers have been specified, which can potentially be involved in the adsorption of $\mathrm{CO}_{2}$ during the injection of gas into the coal seams.
\end{abstract}

\section{Introduction}

According to the international agreement, Poland is obliged to reduce the greenhouse gases emissions to the atmosphere, mainly carbon dioxide $[1,2]$. There are many ways which leads to achieving this condition: reducing fossil fuels burning, improving the energy efficiency of power plants and increasing the share of energy production from renewable sources and nuclear energy. Poland is a state whose national energy is based on fossil fuels and therefore the problem of minimizing the emission of gases into the atmosphere is particularly difficult [3]. Thus, the above mentioned activities may not be sufficient to reduce the global $\mathrm{CO}_{2}$ emissions.

Among the alternatives, one of the most promising ideas is the use of fossil fuels combine with CCS (Carbon Capture Storage) - capture and storage of $\mathrm{CO}_{2}[4,5]$. The idea of storing the carbon dioxide in underground tanks for a long time is termed sequestration of $\mathrm{CO}_{2}$. Therefore, a lot of scientific research is conducted on the possibility of injection and storage of carbon dioxide in deep geological structures, for example anticlines, depleted oil and gas fields. In addition, one of the indicated possibilities are also depleted coal mines.

To be able to apply an innovative method of waste gas emissions disposing by $\mathrm{CO}_{2}$ injection in porous geological deposits, required criteria must be fulfilled (environmental impact and long-term storage). Due to the speciality of heterogeneous coal rocks construction, for each case individual analysis of the gas-coal system must be conducted, in the context of permeability and storage capacity impact of other system components (water, inert gas) on the capacity of the storage center [4].

${ }^{a}$ Corresponding author: azieba@agh.edu.pl

\section{Experimental}

\subsection{Characteristic of the samples}

The research object was the five samples of coal selected from polish mines. Samples of coal have been obtained in accordance with PN-90/G-04502, and then comminuted in a laboratory conditions to a size of 0.5 $1.25 \mathrm{~mm}$, in order to averaging their physicochemical properties. The choice of sites from which samples were taken was dictated by diverse parameters petrographic, chemical and technology.

The Central Mining Institute (GIG) in Katowice made elemental and technical analysis, according to the requirements and procedures laid down in the Polish standards, regarding classification of coal. Parameters of chemical in and technical analysis are summarized in Table 1 and Table 2 . In addition, Table 1 shows special signature of the samples that will be used in the work, instead of the full names of mines because of the clarity and readability of the work.

The content of the basic elements contained in the coal material was examined. Also, the moisture (PN-80/G-04511) and ash (PN-80/G-04512). The oxygen content was calculated as the remainder to $100 \%$, after the moisture and ash content subtraction. Among the selected coals, the smallest content of the elemental carbon in the dry and ash-free state was shown in the coals from the mines: "Bogdanka" (B), "Jankowice" (J) and "Zofiówka" (Z2). The content of the carbon ranged from $75.16-89.06 \%$. The difference could also be observed in the ash content (3.17 - 8.92\%), 
moisture $(0.68-4.36 \%)$ as well as volatile matter 19.72 $36.25 \%$.

Table 1. Chemical (elementary) analysis of the coal samples.

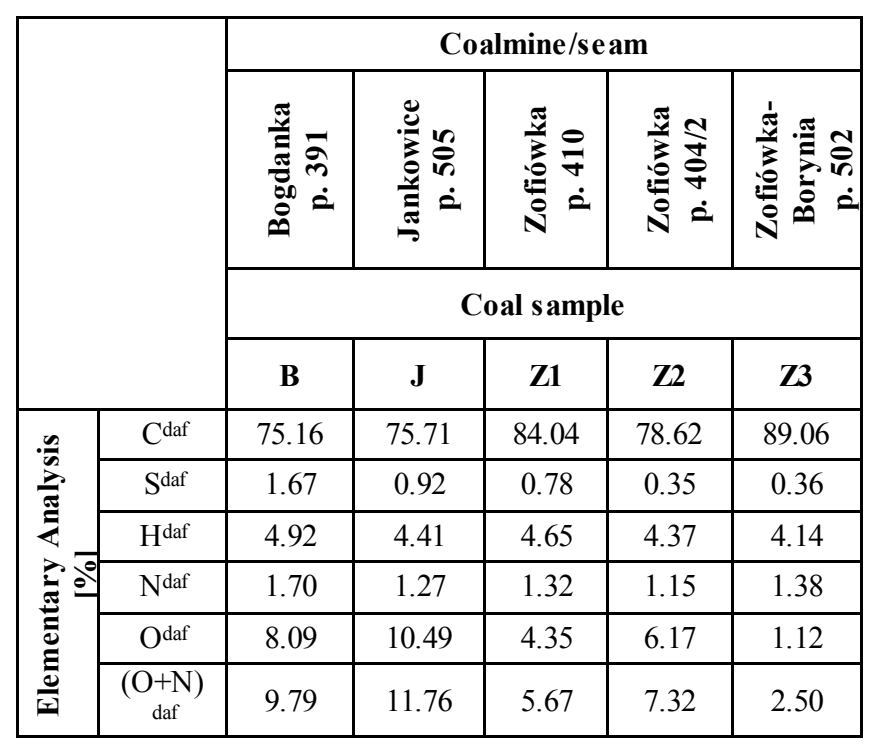

Table 2. Technical analysis of the coal samples.

\begin{tabular}{|c|c|c|c|c|c|c|}
\hline \multicolumn{2}{|c|}{ Coal sample } & B & $\mathbf{J}$ & $\mathbf{Z 1}$ & $\mathbf{Z 2}$ & $\mathbf{Z 3}$ \\
\hline \multirow{3}{*}{ 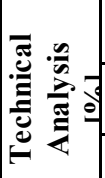 } & $\mathrm{W}^{\mathrm{a}}$ & 4.36 & 2.82 & 1.42 & 0.60 & 0.95 \\
\hline & $\mathrm{A}^{\mathrm{a}}$ & 4.17 & 4.45 & 3.51 & 8.92 & 3.17 \\
\hline & $V^{\text {daf }}$ & 36.25 & 30.93 & 24.53 & 27.93 & 19.72 \\
\hline
\end{tabular}

Explanation: $W^{\text {a: }}$ moisture content, air-dried basis, $A^{\text {a: }}$ ash content, air-dried basis, Vdaf: volatile matter content, air-dried basis, $C^{\text {daf: }}$ content of element $\mathrm{C}$, dry-ash-free basis, $H^{\text {daf: }}$ content of element $\mathrm{H}$, dry-ash-free basis, $N^{\text {daf: }}$ content

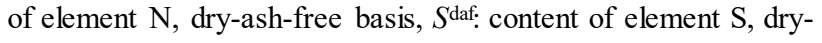
ash-free basis

As an additional characteristic of the research material petrographic analysis was performed. Microscopic studies were carried out using petrographic microscope POLMI type and microscope OLYMPUS. An important parameter characterizing the coal is its reflectivity and the maceral content. Petrographic analysis results (Table 3) shows that selected coals have the light reflectivity value in the range of $0.68-1.3 \%$. The highest index value $R_{0}$ is recorded for the sample $Z 3$, and the smallest for the sample B. The samples differ significantly in the vitrinite content. This value is in the range from $54-91 \%$.

The highest value of this parameter is shown in the sample Z2 and Z3 has the smallest. Number of macerals from the group liptinite and inertinite and ranged as follows: $0-5 \%$ and $8-45 \%$. It is surprising that the sample $\mathrm{Z1}$ did not contained any egzynite, and Z2 contains only minor liptynite and inertynite content.

The selected group of samples contains low, medium and high-carbon coals (Figure 1) as evidence of the relationship between the vitrinite reflectance $\left(\mathrm{R}_{0}\right)$ and the content of volatiles ( $\mathrm{V}^{\mathrm{daf}}$ ).
Table 3. Petrographic analysis of the coal samples.

\begin{tabular}{|c|c|c|c|c|c|c|}
\hline \multirow{4}{*}{ 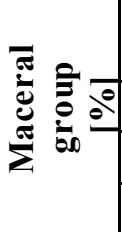 } & Samples & B & $\mathbf{J}$ & $\mathbf{Z 1}$ & $\mathbf{Z 2}$ & $\mathbf{Z 3}$ \\
\hline & vitrynite & 84 & 74 & 88 & 91 & 54 \\
\hline & liptynite & 5 & 3 & 0 & 1 & 1 \\
\hline & inertynite & 11 & 23 & 12 & 8 & 45 \\
\hline \multicolumn{2}{|c|}{$\begin{array}{c}\text { Mineral matter } \\
\text { MM [\%] }\end{array}$} & 0 & 2 & 1 & 4 & 2 \\
\hline \multicolumn{2}{|c|}{$\begin{array}{c}\text { Reflectivity } \\
\mathbf{R}_{0}[\%]\end{array}$} & 0.68 & 0.80 & 1.19 & 1.01 & 1.30 \\
\hline
\end{tabular}

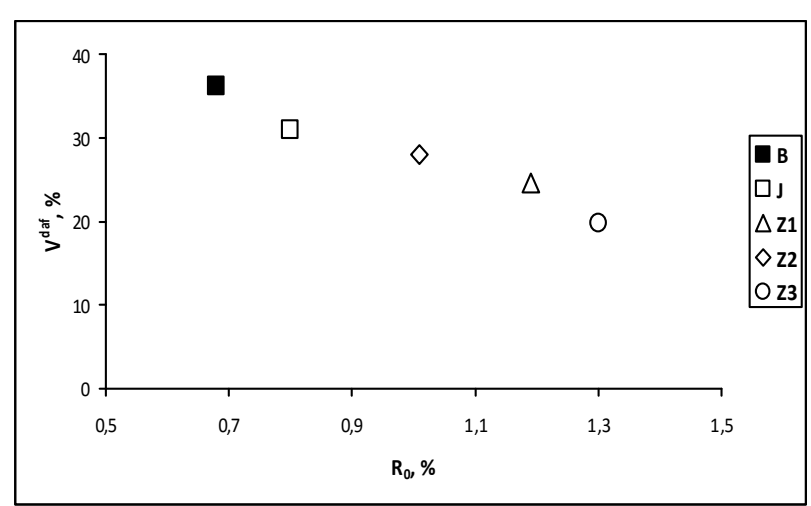

Figure 1. The dependence between the volatile mater content and the vitrinite reflectance of the examinated samples.

The actual density was determined using a camera Micrometrics - Accu Pyc 1330, which is an automatic device for determining the actual density. As pycnometric liquid helium was used. Helium, a non-adsorbant medium, do not react with the tested substance and has great ability to penetrate the porous structure of coals [6].

Table 4. Helium density values for the selected samples

\begin{tabular}{|c|c|c|c|c|c|}
\hline $\begin{array}{c}\text { Coal } \\
\text { sample }\end{array}$ & $\mathbf{B}$ & $\mathbf{J}$ & $\mathbf{Z 1}$ & $\mathbf{Z 2}$ & $\mathbf{Z 3}$ \\
\hline $\begin{array}{c}\mathrm{d}_{\mathrm{He}}, \\
\mathrm{g} / \mathrm{cm}^{3}\end{array}$ & 1.35 & 1.37 & 1.38 & 1.10 & 1.32 \\
\hline
\end{tabular}

Comparing the value $\mathrm{d}_{\mathrm{He}}$ can be seen that carbon $\mathrm{B}$ had the largest true density, and the smallest $\mathrm{Z}$.

\subsection{Sorbate characteristic}

Water molecules are non-linear. The bonds between oxygen and hydrogen are strongly polarized, thus the water has a permanent dipole moment (Table 5) and is strongly polar. Additional advantages of the water as sorbate is the high evaporation heat, thermal stability and non-toxicity [7].

Water used as a sorbate in the process of sorption on the coal is sensitive to the chemical nature of the hard coal, since only the polar sorption occurs [8]. Water vapour is one of the most frequently used sorbate to study the hydrophilicity of hard coal, depending on the metamorphism degree and the fragmentation level of the sample. Water sorption can distinguishe coals very well [9]. 


\subsection{Research methodology}

Adsorption isotherms for selected coals were determined using volumetric apparatus - microburette liquid adsorption type [10] at $303 \mathrm{~K}$ on samples of a grain size $0.5-1.25 \mathrm{~mm}$. Apparatus with liquid microburretes allows to determine isotherms of sorption/desorption polar and apolar vapours at a pressure range from vacuum to the absolute vapour pressure. The construction of the apparatus and the principle of measurement is described in the Klinik's work [11].

Table 5. Selected parameters of the physical and chemical properties of water.

\begin{tabular}{|c|c|c|c|c|c|c|}
\hline $\begin{array}{c}\mathrm{Mm}, \\
{[\mathrm{g} / \mathrm{m}} \\
\mathrm{ol}]\end{array}$ & $\begin{array}{c}\text { Boiling } \\
\text { temper } \\
\text { ature at } \\
\text { atm. } \\
\text { pressur } \\
\mathrm{e}, \mathrm{T}_{\text {nbp }}, \\
{[\mathrm{K}]}\end{array}$ & $\begin{array}{c}\begin{array}{c}\text { Solidific } \\
\text { ation } \\
\text { temperat } \\
\text { ure at } \\
\text { atm. } \\
\text { pressur, } \\
\mathrm{T}_{\mathrm{mp}},[\mathrm{K}]\end{array}\end{array}$ & $\begin{array}{l}\text { Den } \\
\text { sity } \\
\mathrm{d} \mathrm{w} \\
298 \\
{[\mathrm{~K}],} \\
{[\mathrm{g} / \mathrm{c}} \\
\left.\mathrm{m}^{3}\right] \\
\cdot 10^{3}\end{array}$ & $\begin{array}{c}\text { Dipo } \\
\text { le } \\
\text { mom } \\
\text { ent / } \\
{[D]}\end{array}$ & $\begin{array}{c}\text { Vapou } \\
\text { r } \\
\text { pressu } \\
\text { re at } \\
298 \mathrm{~K} \\
{\left[10^{5}\right.} \\
\mathrm{Pa}]\end{array}$ & $\begin{array}{c}\text { Occupi } \\
\text { ed } \\
\text { surface } \\
\text { area } \\
\omega, \\
{\left[\mathrm{m}^{2} / \mathrm{cza}^{2}\right.} \\
\mathrm{st}] \cdot 10^{10}\end{array}$ \\
\hline 18.0 & 373.12 & 273.15 & 997 & 1.82 & 0.0317 & 1.05 \\
\hline
\end{tabular}

Before the sorption measurement the samples had to be properly prepared. Therefore, it is necessary to clean the surface of the samples from the previously absorbed gases and vapours, and also removing from the micropores other, absorbed specific molecules. For this purpose, tested material was degassed to static vacuum $10^{-3} \mathrm{~Pa}$. In addition, to get a better cleaning effect on the surface and porous structure of the research material, several rinsing with helium under pressure was performed. Helium atoms are not significantly being adsorb on the adsorbent surface and provide the necessary kinetic energy for the absorbed particles vapours and gases, thereby knock them from the surface of the sorbent [12]. After each rinse, the sample was again degassed with helium. The prepared samples were than subjected to the experiment. During the investigation the optimal time was chosen in order to reach the state of equilibrium ( 24 hours), after which there was no change in pressure equilibrium.

\section{Analysis}

Sorption/desorption curves for the investigated systems are presented in figures $2-6$. The sorption isotherms are shown as a relation between amounts of absorbed water vapour (a, mmol/g) and the relative pressure $\left(\mathrm{p} / \mathrm{p}_{0}\right)$. The complexity of the physicochemical nature of coal makes the interpretation of the sorption properties of coal in terms of low molecular weight substances as qualitative.

For each coal sample, the adsorption isotherm is the II type, according to the IUPAC classification, which is characteristic for the sorbents containing microand mesopores. It indicates that there is the initial adsorption of a monolayer, followed by the multi layers. Creating a monolayer shows isotherms of sorption at the initial relative pressure range.
Depending on the amount of oxygen, the slope of the isotherm is more or less abrupt. For example, for the carbon samples B and $\mathrm{J}$ filling of the monolayer takes place at a relative pressure of 0.12 and for the sample Z3 monolayer is already filled at 0.07 . This indicates a higher level of $\mathrm{Zl}$ sample coal metamorphism and thus, the presence of a smaller amount of oxygen functional groups which are responsible for the hydrophilic nature of coal and reduced sorption absorbency.

After formation of the adsorption monolayer, successive filling of next layers occurs. Figure 7 corresponds to the passage of the isotherms in a straight line.

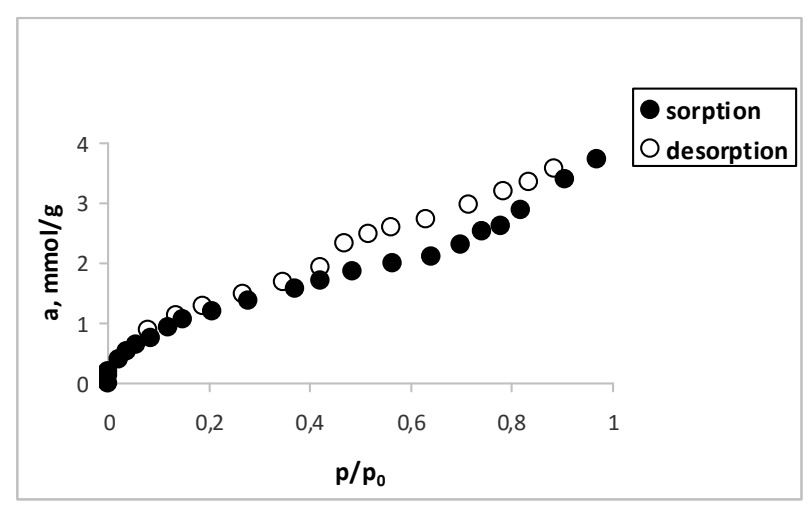

Figure 2. Sorption / desorption isotherm of $\mathrm{H}_{2} \mathrm{O}$ vapour on coal B

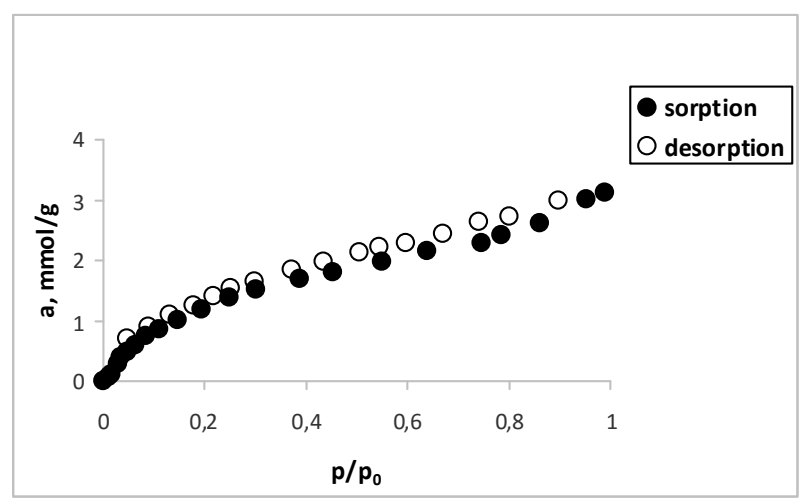

Figure 3. Sorption / desorption isotherm of $\mathrm{H}_{2} \mathrm{O}$ vapour on coal J

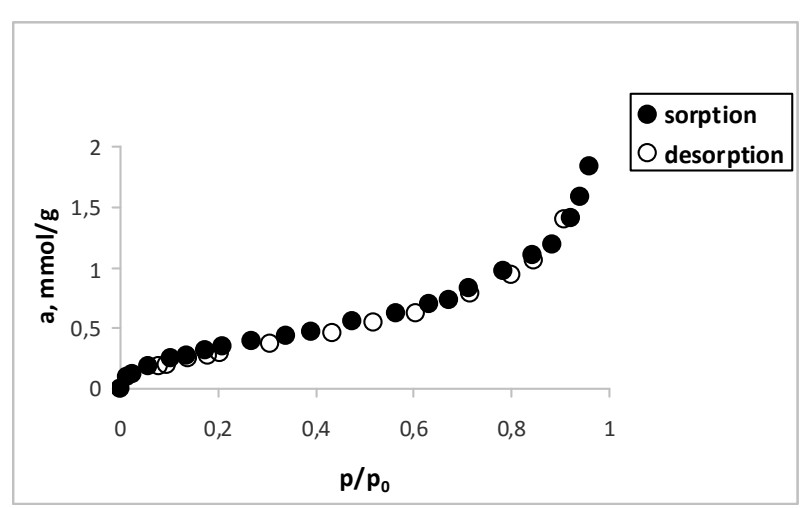

Figure 4. Sorption / desorption isotherm of $\mathrm{H}_{2} \mathrm{O}$ vapour on coal Z1

The degree of successive filling of adsorption layers is closely related to the amount of polar groups, which 
are the sorption centers. Absorbed water molecules become the sorption centers for the next sorbate particles. The process then takes the island nature and clusters are being formed [13]. Isotherms of coals $\mathrm{B}$ and $\mathrm{J}$ indicates that there is a significantly higher secondary sorption surface area when compare with the samples Z1, Z2, Z3. Since these samples are older higher rank coals, they do not contain in their structure so many oxygen species and hence, they have reduced ability to absorb polar water molecules.

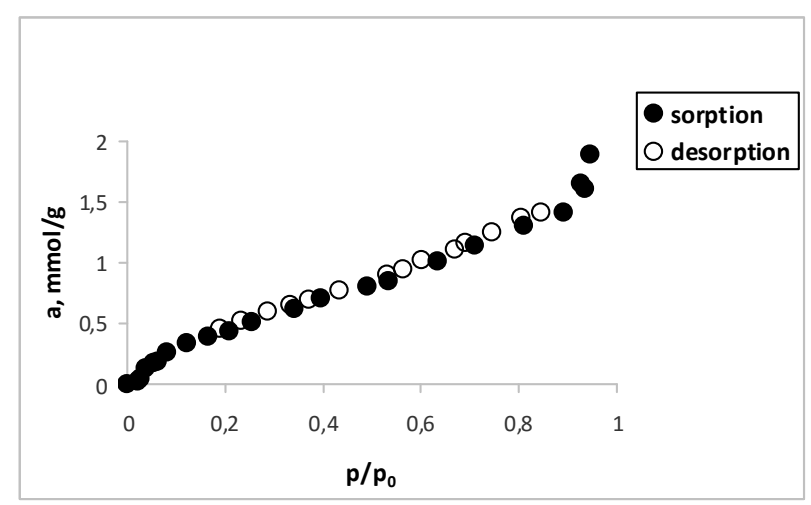

Figure 5. Sorption / desorption isotherm of $\mathrm{H}_{2} \mathrm{O}$ vapour on coal Z2

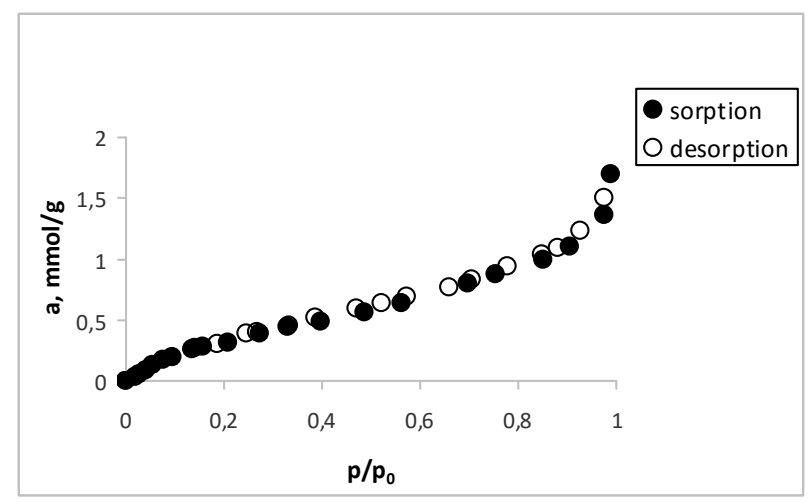

Figure 6. Sorption / desorption isotherm of $\mathrm{H}_{2} \mathrm{O}$ vapour on coal Z3

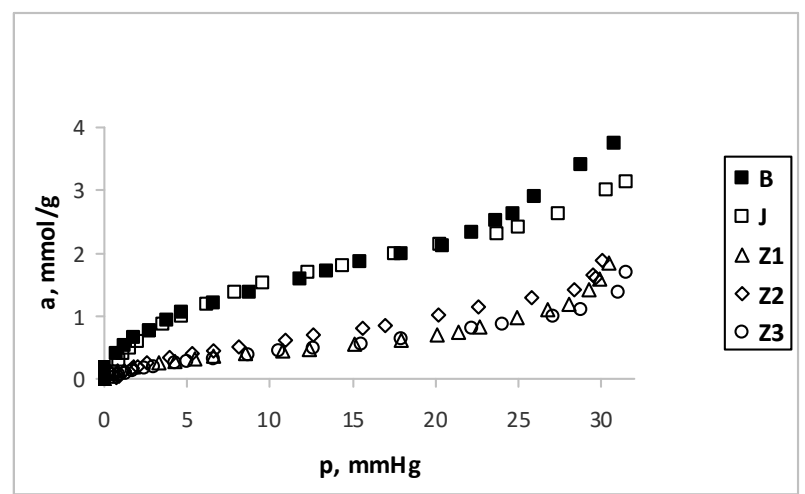

Figure 7. The sorption isotherms of water vapour on selected samples of coal - a comparison of sorption capacity.

Noticeable fact is that the isotherm of carbon Z1, Z2, $\mathrm{Z3}$, in contrast to other coal samples at higher relative pressures tilts upward. This could indicate that there is a phenomenon of coal swelling, or sorbate vapours condense on the inner surface of the pores. However, considering the size of the sorption for the coals $\mathrm{Z1}, \mathrm{Z} 2$,
Z3, significant increase in sorption capacity may be associated with the deposition of sorbate molecules and formation of clusters.

In all cases, on each sorption / desorption curve there is closed hysteresis loop. This fact indicates the presence of capillary condensation. For coals B, J desorption isotherm does not coincide with the sorption isotherm, what indicates a higher degree of chemical sorption when compare with coal samples Z1, Z2, Z3, where desorption and sorption isotherms almost cover each other in the entire range of relative pressures.

Experimental sorption isotherms have been developed by the approximation of a Langmuir and BET linear equation with the measurement data [14]. Knowing that the isotherms of type II compliance experimental data of BET linear equation is in the range of relative pressures between 0.05 to 0.35 and produces a constant linear section is calculated monolayer capacity $\left(\mathrm{a}_{\mathrm{m}}\right)$, and other constant (C) for each sample of coal. The results of calculation for BET theory are given in Table 6.

The monolayer capacity for each coal varies. As expected, absorption capacity is the smallest for coal $\mathrm{Z3}$, with the highest carbon content and the minimum content of oxygen functional groups, responsible for the coal hydrophilicity.

Table 6. The adsorption parameters according to the BET theory

\begin{tabular}{|c|c|c|}
\hline \multirow{2}{*}{ Coal sample } & \multicolumn{2}{|c|}{ BET } \\
\cline { 2 - 3 } & $\mathbf{a}_{\mathbf{m}}$ & $\mathbf{C}$ \\
\hline $\mathbf{B}$ & 1.15 & 18.48 \\
\hline $\mathbf{J}$ & 1.30 & 11.55 \\
\hline $\mathbf{Z 1}$ & 0.36 & 16.32 \\
\hline $\mathbf{Z 2}$ & 0.51 & 9.01 \\
\hline $\mathbf{Z 3}$ & 0.35 & 9.72 \\
\hline
\end{tabular}

There is four times higher oxygen groups presence in coal $\mathrm{J}$, which are the centers of adsorption on the surface of coal. Because of that, to fill the surface with one molecular adsorbent layer there is a need for four more times of water vapour molecules. It is obvious that there is an impact of the oxygen species content on the sorption parameters. Picture 8 shows the relationship between the total content of $\mathrm{O}$ and $\mathrm{N}$ and the size of the sorption. The coal ability to linearly sorb depends on the presence of oxygen functional groups. The more oxygen species in the form of sorption centers, the greater the coals possibility of sorption.

Vitrinite reflectivity is one of the fundamental parameters determining hard coal rank. Figure 9 shows that the samples $\mathrm{Z} 1$ and $\mathrm{Z} 3$, with the highest vitrinite reflectance has the lowest water absorption capacity. In contrast, sorption on coals $\mathrm{B}$ and $\mathrm{J}$ with reflectance order of 0.68 and 0.8 is four times greater than carbon $\mathrm{Z1}$ and $\mathrm{Z3}$.

The content of vitrinite reflects the coal possibility of water vapour absorption. Macerals of vitrinite group are rich in oxygen, as they belong to the youngest macerals. Coals $\mathrm{B}$ and $\mathrm{J}$ with the content of vitrinite respectively $84 \%$ and $74 \%$ have the highest absorption capacity for water. On opposite, coal Z3 with vitrinite 
reflectivity equal $54 \%$ has the smallest sorption capability (Figure 10).

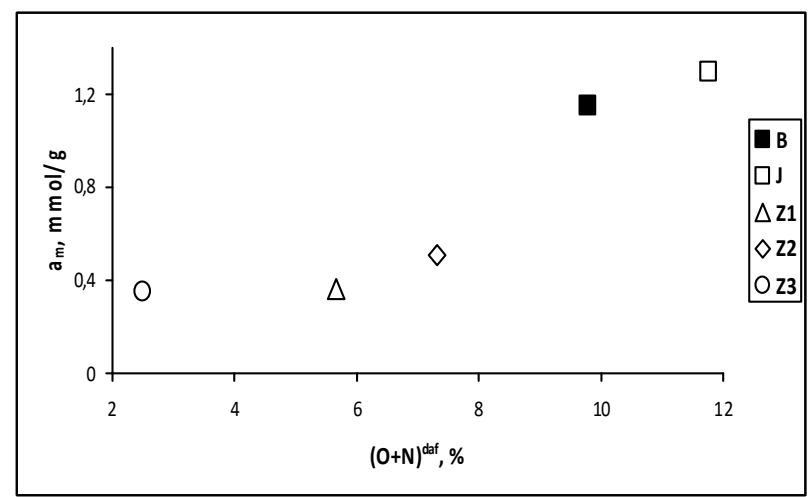

Figure 8. The dependence of the sorption capacity on oxygen and nitrogen content

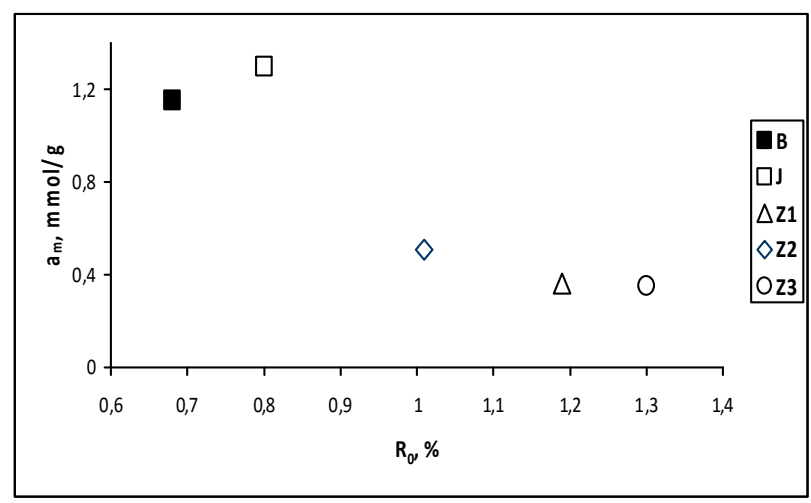

Figure 9. The dependence of sorption capacity on vitrinite reflectivity

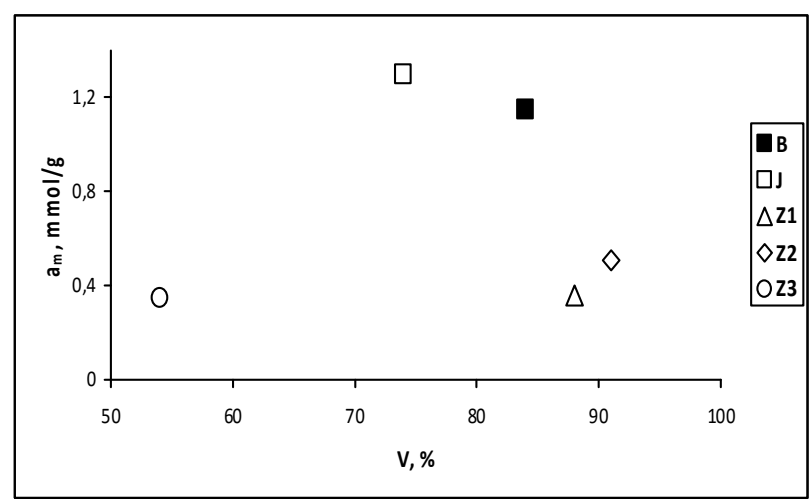

Figure 10. The dependence of the sorption capacity on the vitrinite content

\section{Summary and conclusions}

The object of this investigation was the six coal samples from Polish coal mines. Examined coals differ in the degree of metamorphism. Tests were performed to determine the sorption capacity with the respect to water vapour. From the $\mathrm{CO}_{2}$ capture point of view, it appears to be very important because the presence of moisture in coal sometimes causes a significant reduction in the sorption capacity of coal regarding gases (methane and carbon) [15-17]. Therefore, quantitative analysis determining the water vapour sorption on coal allow us to evaluate the sample in terms of chemical nature, as well as for potential storage center.

As expected [8], studies have shown that the coal with the highest degree of metamorphism (Z3 carbon) showed the lowest sorption capacity. Also, since the oxygen groups, which are closely connected with the coal rank, are responsible for the amount of sorption centers, their presence is the most important factor influencing the sorption capacity of coal. They are also responsible for the chemical nature of the carbon surface, which hydrophilic properties are increasing with higher number of these groups.

Carbons B and $\mathrm{J}$ showed the highest ability to absorb water vapour, which is closely related to the amount of oxygen species on their surface. Z3 coal, which has the highest content of carbon and the lowest number of reactive oxygen groups, absorbed the least amount of water molecules from the tested samples.

It is therefore necessary to stress once again that in the deliberations on the underground storage of $\mathrm{CO}_{2}$, the storage capacity in relation to this gas may not be the most important parameter in assessing the suitability of such deposits. It is important to determine the sorption capacity of water vapour on the coal, and even better, to determine the absorbency of $\mathrm{CO}_{2}$ on coal pre-saturated with $\mathrm{H}_{2} \mathrm{O}$.

\section{Acknowledgments}

Financial support for this study was provided by the AGH University of Science and Technology (framework no. 11.11.210.244).

\section{References}

1. C.M. White, D.H. Smith, K.L. Jones, A.L. Goodman, S.A. Jakich, R.B. LaCount, S.B. DuBose, E. Ozdemir, B.I. Mors, K.T. Schroeder, Energy \& Fuels, 19, 659-724, (2005)

2. G.X. Wang, P. Massarottoa, V. Rudolpha, International Journal of Coal Geology, 77, 127-136, (2009)

3. A. Wójcicki, Przeględ Geologiczny, 57, 138-143, (2009), in Polish

4. Y. Gensterblum, A. Busch, B.M. Krooss, Fuel, 115, 581-588, (2014)

5. M. Wdowin, R. Tarkowski, W. Franus, International Journal of Coal Geology 130, 79-88, (2014)

6. Rao M.B. Carbon, 29 (1991) 813-815

7. J. Gancarz, Woda, Wydawnictwa Szkolne i Pedagogiczne, Warszawa, (1975), in Polish

8. K. Kreiner, M. Żyła, Górnictwo i Geoinżynieria, AGH, R. 30, z. 2, 19 - 34, Kraków, (2006) in Polish

9. A. Orzechowska - Zięba, Rozprawa doktorska, AGH, Kraków, (2009) in Polish

10. M. Lasoń, M. Żyła, Chemia Analityczna, 8, 279 286, (1963), in Polish

11. J. Klinik, Tekstura porowatych ciał stałych, Ośrodek Edukacji Niestacjonarnej, Kraków, (2000), in Polish 
12. S. Saha, B.K. Dharma, S. Kumar, G. Sahu, Y.P. Badhe, S.S. Tambe, B.D. Kulkarni, Fuel, 86, 1594-1600, (2007)

13. K. Kreiner, M. Żyła, P. Baran, Gospodarka Surowcami Mineralnymi, 23, zeszyt specjalny nr 3, 167-174, (2007), in Polish

14. J. Ościk, Adsorpcja, Powszechne Wydawnictwo Naukowe, Warszawa, (1983), in Polish

15. J.I. Joubert, C.T. Grein, D. Bienstock, Fuel, Vol. 52, Issue 3, 181-185, (1973)

16. C.R. Clarkson, R.M. Bustin, International Journal of Coal Geology, Vol. 42, Issue 4, 241-271, (2000).

17. P.J. Crosdale, T.A. Moore, T.E. Mares, International Journal of Coal Geology, Vol. 76, Issues 1-2, 166174, (2008) 